\title{
Effectiveness analysis of accounting outsourcing transition***
}

\author{
Galyna Lyakhovich $^{1}$, Mykola Horodysky ${ }^{2}$, Irina Hrabchuk ${ }^{3}$, Oksana Vakun ${ }^{4}$ \\ ${ }^{1}$ Doctor of Economics, Assistant Professor, \\ Professor of the Department of Public Management and Governance, \\ Ivano-Frankivsk Educational and Scientific Institute of Management, Ternopil National Economic University \\ ${ }^{2} \mathrm{PhD}$ in Economics, \\ Assistant Professor of the Department of Accounting and Auditing, \\ Zhytomyr Polytechnic State University \\ ${ }^{3} \mathrm{PhD}$ in Economics, \\ Assistant Professor of the Department of Accounting and Auditing, \\ Zhytomyr Polytechnic State University \\ ${ }^{4} \mathrm{PhD}$ in Economics, \\ Assistant Professor of the Department of Public Management and Governance, \\ Ivano-Frankivsk Educational and Scientific Institute of Management, Ternopil National Economic University
}

JEL Classification: M41

\begin{abstract}
To ensure the best performance, businesses outsource individual business processes. However, implementing this step requires evaluating the effectiveness of such actions. The purpose of the article is to develop a techniques for analyzing the economic effectiveness of the transition to accounting outsourcing. To achieve the purpose, a critical evaluation of the approaches of scientists to determine the effectiveness of outsourcing has been made. Considering the identified
\end{abstract}

Corresponding author:

${ }^{1}$ E-mail address: rokcoljana@ukr.net

ORCID ID: 0000-0002-0077-9128

${ }^{2}$ E-mail address: m.p.gorodysky@ukr.net

ORCID ID:00oo-0002-2093-5263

${ }^{3}$ E-mail address: grabchuk0208@gmail.com

ORCID ID: 0000-0003-3664-7765

${ }^{4}$ E-mail address: vakyn.o@gmail.com

ORCID ID: 0ooo-0002-7774-7204

(C) 2020 G.Lyakhovich, M.Horodysky, I.Hrabchuk, O.Vakun

doi: https://doi.org/10.26642/ppa-2020-1-30-43 


\begin{abstract}
disadvantages and advantages, as well as practical experience, the process of decision making on accounting outsourcing and evaluating its effectiveness is structured. The composition of the elements of the costs of maintaining accounting at the enterprise has been defined in the article. In order to evaluate the effectiveness of outsourcing the company it is suggested to use a technique that takes into account the indicators: timeliness of works and services under the terms of the outsourcing agreement; completeness of works and services under the terms of the outsourcing agreement. The technique was tested on five enterprises in different industries that planned to outsource accounting functions. It is established at what enterprises it is possible to achieve cost reduction and increase of effectiveness of resources use in the case of accounting outsourcing transition.
\end{abstract}

Keywords: accounting; accounting outsourcing; effectiveness; outsourcer.

\title{
1. Introduction
}

Accounting outsourcing decision cannot be spontaneous and requires careful consideration. Unless keeping records on its own is not decisive for the entity, it is advisable to outsource accounting functions. However, separate accounting areas cannot be transited to outsourcing due to the fact that they are connected with commercially confidential data (for example, production accounting due to the need to eliminate the threat of production technology leakage).

The study of different approaches to determining the feasibility of transition to outsourcing does not give a clear answer to the question of which method is most effective. The results of the study show that the choice of one or another method depends on the characteristics of the enterprise, the purpose of the transition to outsourcing and information support of the analysis of such a process.

\section{Literature review}

Currently, there is a considerable number of both foreign and domestic articles that offer different models and methods of justifying the feasibility of outsourcing as a whole, primarily related to different approaches to assessing the effectiveness and variety of types of outsourcing, for each of which individual calculation can be offered.

Modern methods of assessing the feasibility of outsourcing can be roughly grouped into two groups: schematic (using matrixes) and settlemet economic. The matrixes most commonly used by consulting companies include outsourcing matrix K.Vitasek and M.Ledyard (2013); matrix of outsourcing of Ronan McIvor, Paul K. Humphreys, Anthony Wall, Alan McKittrick (2009); matrix of outsourcing of Mingu Kang, Xiaobo Wu and Paul Hong (2009); Kurbanov's model (Isavnin \& Farkhoutdinov, 2013). The study of settlement and economic of outsourcing justification has shown that basically evaluating its effectiveness includes comparison of its own costs and outsourcing costs, which was done in the works of Anikin, Rudaya (2017), Davydkin (2011), Dubrovskaya (2016), Shmigol (2010), Skakun (2010).

In particular, Shmigol (2010, p. 194) argues that the cost-effectiveness of outsourcing is only ensured if the manufacturer's total outsourcing costs do not exceed its costs of implementing this business process on its own. If this condition is not fulfilled, then the business process is better performed on its own. Outsourcing costs are closely linked to assessment of their effectiveness, which is often compared to an estimate of return on investment (Giertl, Potkány \& Gejdoš, 2015). Despite the versatility of using this metric, the issue of identifying transaction costs for outsourcing is often underestimated in practice.

Anikin and Rudaya (2017) suggest to use only the costs that disappear when using outsourcing to estimate their own costs. If the cost of own production is less than the cost of purchasing outsourcing services, then the use of outsourcing is economically justified, otherwise it is inappropriate because it will not lead to cost reduction.

In addition, many researchers and practitioners use the classic approach to evaluating effectiveness in order to justify the feasibility of outsourcing, which involves a correlation between the effect and the costs (resources used) in different forms.

\section{The identification of previously unresolved issues and the formulation of research hypotheses}

Current techniques, as a rule, consider the effectiveness of accounting outsourcing already in the implementation phase, but do not take into account the expediency of transition to this form of accounting organization. In no way diminishing the value of the expertise of the predecessors, we consider it appropriate to justify a technique that would take into account the areas of accounting that are transited to outsourcing, the criteria for choosing an outsourcer.

It is necessary to offer a technique that can be applied to entities with any form of accounting organization and used in the Ukrainian realities of outsourcing services market development, since this market is highly competitive and developed.

The purpose of the study is to develop a technique for analyzing the cost-effectiveness of the transition to accounting outsourcing. To achieve this goal, the following scientific tasks are defined:

1. Generalization of approaches to assess the feasibility of accounting outsourcing transition.

2. Disclosure of indicators to evaluate the effectiveness of accounting outsourcing at the decision-making stage.

3. Test the suggested technique for assessing the feasibility of accounting outsourcing transition. 


\section{Research methodology and methods}

The methodological basis of the study is the principles of transaction cost theory, which is used for a long time in determining the choice between vertical integration and outsourcing, which led to its consideration in justifying the expediency of transition accounting functions to outsourcing.

The information base of the research is monographs, professional scientific articles of Ukrainian and foreign scientists, materials of scientific and practical conferences of domestic and foreign scientists on the development of theoretical and methodological principles of accounting outsourcing.

The theoretical generalizations and reasoning of the author's conclusions are based on the use of comparative analysis to study approaches to assessing the effectiveness of the transition to accounting outsourcing.

The use of an empirical approach has facilitated the analysis of information material and survey data of business entities' management staff, which discusses the feasibility of implementing accounting outsourcing. The study focuses on the activities of small Ukrainian businesses in various industries whose management has sought to reduce the cost of accounting.

\section{Main results}

One of the key areas for improving the activity of business entities is optimization, refusal of non-core functions that do not bring value to the consumer and the enterprise, but the implementation of which is necessary for the existence and development of the entity itself.

As noted by Eggertsson (2001), within neoinstitutional theory, a resource is used effectively when it is available to the user for whom it is of the highest value. Similarly distributed are those resources used to organize and maintain accounting. Minimization of transaction costs in accounting is possible due to the transition of this business process to outsourcing, since accounting is one of those functions of the entity that do not create additional benefits for consumers, do not create added value to the enterprise, but are necessary to ensure its activity.

The cost-effectiveness of outsourcing implementation is assessed taking into account all types of risks associated with the transition of business processes to a third party. There are two main ways to evaluate outsourcing effectiveness:

- single criterion,

- multi-criteria.

Single criterion approach involves determining the impact of outsourcing on only one of the characteristics of the entity, most often the financial results, and as an indicator of valuation is the additional income or savings that are generated when using outsourcing. On the whole, this approach is fully consistent with the theory of transaction costs, which we have chosen as a theoretical basis for analyzing the accounting outsourcing effectiveness. The multi-criteria method contains an assessment of the impact of outsourcing on various factors of entity activity (Kotlyarov, 2010, p. 88).

According to the single criteria approach, resource saving in accounting outsourcing can be determined by the formula:

$$
S=\sum_{i=1}^{n} C_{i}-P_{i}
$$

where $S$ - resource saving;

$n$ - number of years of using outsourcing;

$i$ - year of using outsourcing;

$C_{i}$ - expenses on record keeping by the entity;

$P_{i}$ - expenses on record keeping by outsourcer.

To adjust the obtained result to the change in the value of money over time (i.e. adjusting for inflation), formula (1) can be modified (formula 2):

$$
S=\frac{\sum_{i=1}^{n} C_{i}-P_{i}}{\left(1+\frac{d}{100}\right)}
$$

where $\mathrm{d}$ - discount rate.

Although formula (2) makes it possible to calculate more accurately (taking into account changes in the value of money over time) the saving generated by outsourcing, there is no appreciable change in determining the structure of the economic effect of outsourcing. The fact is that this formula does not take into account transaction costs for searching the outsourcer as well as saving resources due to the liquidation of accounting service.

Let's include in the formula 2 the specified indicator:

$$
S=\frac{\sum_{i=1}^{n} C_{i}-P_{i}}{\left(1+\frac{d}{100}\right)}-C_{0}+D_{0}
$$

where $C_{0}$ - one-off costs associated with the transition to outsourcing;

$D_{0}$ - one-off revenue associated with the transition to outsourcing. 
These components make it clear that during the implementation of outsourcing, there is a restructuring of the entity, which involves the liquidation of the accounting service, which previously provided the process transmitted to outsourcing.

Formulas (1) - (3) consider only the financial component of outsourcing implementation effectiveness, which in turn makes the situation much easier, but nevertheless limits the entity in getting a full picture of all the consequences of outsourcing, both negative and positive.

Discounted income and expenses method allows to take into account the change in the value of money over time, but it feresees that accounting is considered as one of the business processes in the entity that participates in the formation of expenses and indirectly ensures the formation of income.

$$
E_{f f}=\sum_{i=1}^{n} \frac{E_{i}}{(1+d)^{i}}+\sum_{i=1}^{n} \frac{R_{i}}{(1+d)^{i}}+\sum_{i=1}^{n} \frac{A_{i}}{(1+d)^{i}}-C_{0}-\sum_{i=1}^{n} \frac{C_{i}}{(1+d)^{i}}-\sum_{i=1}^{n} \frac{T_{i}}{(1+d)^{i}},
$$

where $E_{f f}$ - the economic effect of outsourcing usage;

$n$-duration of outsourcing agreement (number of years);

$d$ - discount rate;

$E_{i}$ - the cost savings from outsourcing received in i-th year is the difference between the expenses of the enterprise to carry out a particular process on its own and the expenses associated with transition of process to outsourcer;

$R_{i}$ - additional income in the i-th year, obtained from the outsourcing use (increase in cost due to quality improvement, increase in revenue through improved entity image);

$A_{i}$ - other customer income in the i-th year resulting from outsourcing use (income from the sale or lease of surplus property, reduction of property taxes);

$C_{0}$ - costs of searching the outsourcer;

$C_{i}$ - costs of outsourcing management in i-th year (administrative, transportation expenses);

$T_{i}$ - costs of transition to outsourcing in i-th year (business process reengineering, equipment purchase, compensation for redundant employees).

If $E_{f f}>0$ and has a maximum value, then outsourcing is recommended. Thus, the economic effect is again calculated on the basis of how much the costs of the entity have been reduced due to the use of outsourcing.

The main advantage of this approach is that it contains a complete list of possible sources of additional costs and income for the entity when using outsourcing.

But this method does not take into account the fact that, in addition to achieving a positive economic effect, a company must exceed a certain limit value $E_{f f_{\min }}$, because if $E_{f f}<E_{f f_{\min }}$, then the obtained economic effect is insufficient to offset all costs associated with outsourcing, including alternative costs. In addition, the formula does not take into account the risk of adverse changes in the environment or poor performance of the outsourcer, regarding the incorrect determination of the predicted value of the economic effect.

Assessing the outsourcing effectiveness Kotlyarov (2013, pp. 9-13) suggests to modify the method described above to take into account these risks, while indicating that the cut-off value of the economic effect $E_{f f_{\min }}$ must be greater than the amount of losses entity may incur in case of risk situation.

For the convenience of describing the method formula (4) is represented in the form of formula (5):

$$
E_{f f}=E+R+A-C_{0}-C-T
$$

where $E=\sum_{i=1}^{n} \frac{E_{i}}{(1+d)^{i}}$;

$R=\sum_{i=1}^{n} \frac{R_{i}}{(1+d)^{i}}$;

$A=\sum_{i=1}^{n} \frac{A_{i}}{(1+d)^{i}}$

$C_{0}$ - expenses on searching the outsourcer;

$C=\sum_{i=1}^{n} \frac{C_{i}}{(1+d)^{i}}$

$T=\sum_{i=1}^{n} \frac{T_{i}}{(1+d)^{i}}$.

Taking into the consideration the author's assumption, the economic effect of outsourcing is calculated as follows:

$$
E_{f f}=W_{E} E+W_{R} R+W_{A} A-C_{0}-C-T \geq W_{L} L
$$

where $W_{E}, W_{R}, W_{A}-$ the probability that the entity will receive income;

$W_{L} L-$ the probability that the entity will suffer losses;

$L$ - expected loss of the entity.

The values of these probabilities are determined by expert judgment.

The next step after determining the probabilities is to set company limits: $W_{E}^{\min }, W_{R}^{\min }, W_{A}^{\min }, W_{L}^{\max }, L_{\max },\left(W_{L} L\right) \max$. 
This system must comply inequalities:

$$
\left\{\begin{aligned}
\left(W_{L} L\right) \max & \leq W_{L}^{\max } L_{\max }, \\
W_{E}^{\min } & \geq W_{L}^{\max }, \\
W_{R}^{\min } & \geq W_{L}^{\max }, \\
W_{A}^{\min } & \geq W_{L}^{\max }
\end{aligned}\right.
$$

Thus, outsourcing transition will be advisable if the following conditions are met:

$$
\left\{\begin{array}{c}
E_{f f}>W_{L} L, \\
W_{L} \leq W_{L}^{\text {max }}, \\
L \leq L_{\text {max }} \\
W_{L} \leq\left(W_{L} L\right)_{\max }, \\
W_{E} \geq W_{E}^{\text {min }}, \\
W_{R} \geq W_{R}^{\text {min }}, \\
W_{A} \geq W_{A}^{\text {min }} .
\end{array}\right.
$$

Using this formula allows to calculate the economic effect of outsourcing use, taking into account the probabilities of achieving the necessary factors contributing to the additional income for the entity that ordered outsourcing services. The disadvantage of this technique is that all necessary probability values are determined by expert estimates, that is, are subjective one. In addition, another problem arises - the search for appropriate experts, which makes this technique a problem for practical application.

Analyzing the feasibility of applying accounting outsourcing using the single-criterion method does not include such important risks as the loss of one's competencies in outsourced functions, dependence on a third party, deprivation of complete quality control of outsourced business processes. However, such drawbacks are relative, considering conditions of contract theory such as asset specificity and uncertainty.

The effort to compensate the shortcomings of the single-criteria method was the basis for developing a multi-criteria approach to determining outsourcing effectiveness. Using the logic of a multi-criteria approach, it can be formalized as follows:

$$
S=\sum_{i=1}^{n} W_{i}\left(K A_{i}-K B_{i}\right)
$$

where $S$ - the effect of outsourcing;

$\mathrm{n}$ - number of criteria evaluated;

$W_{i}$ - the weight of the $\mathrm{i}$-th criterion in the overall score;

$K A_{i}$ - the value of the $\mathrm{i}$-th criterion after the outsourcing implementation;

$K B_{i}$ - the value of the $\mathrm{i}$-th criterion before the outsourcing implementation.

Since formula (9) uses different indicators, they must first be reduced to a single scale. After that, the effect of accounting outsourcing is calculated. However, if in a single criterion approach the effect is determined in monetary terms, in a multi-criteria approach the effect is determined in indices or coefficient values. This is the complexity of using this approach, as different qualitative indicators need to be brought to a single measurement base for their additivity. Typically, such a base is indexes.

Analyzing formula (9), we can conclude that multi-criteria methods also have disadvantages. One of these disadvantages is their «compensation problem». Since the above technic is additive, the decrease in the value of one of the criteria can be offset by the increase in the value of the other. Ultimately, the overall effectiveness of accounting outsourcing will be positive.

However, this problem can be quite acute for those entities for which the decisive importance is not so much the saving of resources in monetary terms, but the optimization of the entity. Therefore, in this case, the leveling of factor variables can be negative for the quality of the analysis. Such characteristic features of the multi-criteria approach somewhat narrow the scope of its application.

In contrast to the previous drawback, the final index, expressed in index form, is devoid of economic content. This disadvantage is important in that it does not give an idea of the economy of resources in the context of transaction costs theory, and therefore it is impossible to characterize the economic effect of accounting outsourcing on its basis.

When analyzing the impact on an entity of any of the factors, it is important to consider that the entity is a system (that is, has an internal environment) and functions in relation to the external environment. From this it follows that the implementation of outsourcing should help to improve the internal environment of the entity and its interaction with the external environment (in other words, to strengthen the position of the entity in relations with counterparties). Such improvement is a positive effect of accounting outsourcing.

The criteria included in the multi-criteria method should objectively describe the state of the internal environment of the entity and its interaction with the external environment (which include, for example, competitors, suppliers, marketing intermediaries, consumers, public authorities, etc.). 
In this study, and in accordance with transaction costs theory, we will focus on the economic effect of accounting outsourcing, since its goal, according to the theoretical concept chosen, is to save the entity resources by reducing transaction costs. The basic formula for determining the effect of outsourcing is Formula 7, which allows to evaluate the long-term effect. However, only the data available at the time of making that decision is available to management at the decision-making stage of the transition to outsourcing. From this it follows that over time, the effect of outsourcing may change with changes in inflation, salaries, etc.

Now it is necessary to fill the basic formula (formula 7) with variables. Variables of this mathematical model are the components of the costs elements that ensure the execution of accounting functions that are outsourced, that is, the costs of keeping records. In general, a list of such costs is given in Table 1.

Table 1

Cost elements for keeping records at the enterprise

\begin{tabular}{cl}
\hline Symbol & Cost element name \\
\hline$k_{1}$ & Salaries and other payments to accounting staff \\
\hline$k_{2}$ & Charges from salaries and payments to accounting staff \\
\hline$k_{3}$ & Material costs (office supplies, office equipment costs, etc.) \\
\hline$k_{4}$ & Depreciation of property, plant and equipment used for keeping records \\
\hline$k_{5}$ & Training and professional development of accounting staff \\
\hline$k_{6}$ & Accounting software costs for keeping records \\
\hline$k_{7}$ & Acquisition costs of professional periodicals \\
\hline$k_{8}$ & The cost of repairing the premises \\
\hline$k_{9}$ & The cost of telecommunication means (telephone, Internet) \\
\hline$k_{10}$ & Fixed costs in the part allocated to the accounting service
\end{tabular}

It should be noted that this list of costs is non-exhaustive and can be supplemented on the basis of the specifics of each individual entity. In this case, the index value reflects the number of cost elements for the implementation of accounting functions of the entity. The costs of accounting functions are denoted as $\sum k_{i}$.

Let's consider in more detail the components of the economic model represented by formula 7.

Costs of keeping records by the entity on its own $\left(C_{i}\right)$ can be expressed in the following form:

$$
C_{i}=\sum_{i=1}^{n}\left(k_{1}, k_{2}, k_{3}, k_{4}, k_{5}, k_{6}, k_{7}, k_{8}, k_{9}, k_{10}\right)
$$

The costs of performing accounting functions by an outsourcing company are expressed in the following form:

$$
P_{i}=C_{t}+E C_{t}
$$

where $C_{t}$ - the basic cost of accounting outsourcing services;

$E C_{t}$ - additional costs for communication between the customer and the accounting outsourcing company.

In the economic literature and research on outsourcing, there is one more component that is credited to the costs of keeping records by an outsourcer, in particular Alyoshina (2014) suggests a adjustment coefficient. This adjustment coefficient is intended to take into account the specifics of the implementation of a specific outsourcing project performed by the outsourcer. The magnitude of this coefficient can be calculated by comparing the value of the outsourcing services market proposals on the specific features of business processes in a particular outsourcing customer. The adjustment coefficient is defined as follows:

$C_{\text {adj }}=C_{\text {org }} \times C_{\text {serv }}\left\{C_{F E A}, C_{V A T}, C_{\text {det }}, C_{g e n}, \ldots C_{\mathrm{T}}\right\}$

where $C_{a d j}$ - adjustment coefficient;

$C_{\text {org }}$ - a coefficient that takes into account the amount of outsourcing from an organizational point of view, such as full (implementation of accounting outsourcing of accounting functions with elements of personnel and legal outsourcing) or partial (implementation of accounting outsourcing functions with elements of personnel outsourcing), etc.

$C_{\text {serv }}$ - a coefficient that takes into account the increased cost of outsourcing through the business processes of a specific outsourcing customer. This coefficient, in turn, depends on some set of coefficients that reflect the contribution of these economic processes.

The coefficient $C_{\text {serv }}$ can be represented, for example, by the product of such coefficients:

$$
C_{\text {serv }}=\left\{C_{F E A}, C_{V A T}, C_{\text {det }}, C_{g e n}, \ldots C_{\mathrm{T}}\right\}
$$

where $C_{F E A}, C_{V A T}, C_{d e t}, C_{g e n}, \ldots C_{\mathrm{T}}$ - coefficients that take into account the increase in the cost of outsourcing due to the presence of transactions on foreign economic activity, if the company is a VAT payer, if the company has separate branches (offices, representative offices), if the company goes from a simplified system of taxation to the general system, etc. 
Based on a study of the economic activity of small industrial enterprises, Alyoshina (2014) concludes that these coefficients can be calculated by other methods. The author gives the values of the coefficients that were calculated on the basis of information obtained from open sources (advertising in the media, the Internet). In this case, $C_{a d j}$ is calculated as the product of the coefficients $C_{\text {org }}$ and $C_{\text {serv }}$. The data on the values of the coefficients are shown in Table 2.

Table 2

Matrix of adjustment coefficients

\begin{tabular}{cccccc}
\hline \multirow{2}{*}{$\mathrm{C}_{\text {org }}$} & \multicolumn{5}{c}{$\mathrm{C}_{\text {serv }}$} \\
\cline { 2 - 6 } & $\mathrm{C}_{\text {FEA }}$ & $\mathrm{C}_{\mathrm{VAT}}$ & $\mathrm{C}_{\text {det }}$ & $\mathrm{C}_{\text {gen }}$ & $\mathrm{C}_{\mathrm{T}}$ \\
\hline Value of components $\mathrm{C}_{\text {serv }}$ & 1,15 & 1,15 & 1,15 & 1,10 & 1,10 \\
\hline Basic accounting services & 1,00 & 1,00 & 1,00 & 1,00 & 1,00 \\
\hline
\end{tabular}

We believe that this approach is noteworthy, but its implementation may not be practical. The fact is that these ratios are calculated by the company that wants to outsource accounting. An outsourcing company, in turn, can take a completely different approach to determining the value of its services. At the same time, it is clear that it will take into account the individual features of each client and adjust the cost of outsourcing services in accordance with factors that complicate or expand the scope of work.

However, in the context of transaction cost theory, the benefits that an entity gets from reducing transaction costs as a result of outsourcing business processes are not just about saving resources. A number of other effects are also achieved, such as optimizing the structure of the entity and organizing of its activities.

Porter (2006) argues that a company's competitive advantage is created by coordinating relationships in the value chain outside the company's business. Sourcing models (finding the right supplier, manufacturer, product) are a necessary tool for such coordination. The main sourcing models include: insourcing; outsourcing; multisourcing.

The centralization of business processes is observed in the insourcing, thus increasing the controllability of production processes. Subsequently, this structure becomes complex and effectiveness decreases. The solution to this issue is to use management technologies such as outsourcing. When outsourcing non-core functions to outside organizations, it is difficult to identify key processes that are strategically important to the entity. With the accumulation of experience in interacting with the outsourcers, as well as for avoiding the dependence on a single supplier, companies switch to multi-sourcing (having multiple service providers).

Effective activity is one that ensures that the desired effect is achieved. When considering the issues of accounting outsourcing, it should be understood that the effectiveness of such outsourcing should be considered in two respects. The first aspect is related to cost effectiveness, that is, to save the internal resources of the entity by transition business processes from accounting to outsourcing. The second aspect is related to the effectiveness of the outsourcing company and the smooth functioning of the entity that used the outsourcing services.

In order to evaluate the effectiveness of the company's outsourcing service, we consider it advisable to use a methodology based on the company's performance metrics:

Timeliness of works and services under the terms of the outsourcing agreement:

$$
\mathrm{E}_{\text {time }}=\mathrm{T}_{\mathrm{t}} / \mathrm{T}_{\mathrm{t} 0}
$$

where: $\mathrm{E}_{\text {time }}$ - time outsourcing coefficient;

$\mathrm{T}_{\mathrm{T}}-$ actual time of accounting outsourcing services;

$\mathrm{T}_{\mathrm{T} 0}-$ scheduled under the terms of the agreement time to provide accounting outsourcing services.

The accounting outsourcing service final value of time coefficient may vary from 0 to 1 . In the case when the coefficient value is 0 , this means that the actual time of accounting outsourcing services is scheduled, that is, the outsourcing company has fully fulfilled the terms of the agreement in terms of timeliness of the undertaken obligations.

Completeness of performance of works and services rendering according to the terms of the outsourcing agreement:

$$
\mathrm{E}_{\mathrm{volume}}=\mathrm{Q}_{\mathrm{act}} / \mathrm{Q}_{\mathrm{p}}
$$

where: $\mathrm{E}_{\mathrm{volume}}$ - coefficient of the volume of accounting outsourcing services;

$\mathrm{Q}_{\text {act }}$ - volume of accounting outsourcing services actually provided (for the relevant period of time);

$\mathrm{Q}_{\mathrm{p}}$ - the volume of accounting outsourcing services planned under the terms of the agreement (for the relevant period of time).

The final value coefficient of the performance of works and services rendering completeness of accounting outsourcing may also range from 0 to 1 . If the coefficient is 0 , the actual volume of accounting outsourcing services rendered is as planned.

Cost-effectiveness of outsourcing, calculated by comparing the actual costs of outsourcing and planned under the terms of the agreement:

$$
\mathrm{E}_{\mathrm{eff}}=\mathrm{C}_{\mathrm{act}} / \mathrm{C}_{\mathrm{agr}}
$$


where $\mathrm{E}_{\text {eff }}$ - coefficient of efficiency;

$\mathrm{C}_{\mathrm{act}}$ - actually incurred costs on outsourcing;

$\mathrm{C}_{\mathrm{agr}}-$ the amount of costs defined in the outsourcing agreement.

When evaluating the outsourcing effectiveness, each of the above criteria should have its own weight coefficient. All the coefficients are combined into a single integrated performance metric.

$$
\mathrm{E}_{\text {integr }}=\mathrm{E}_{\text {time }}{ }^{\mathrm{x}} * \mathrm{E}_{\mathrm{volume}}^{\mathrm{y} *} \mathrm{E}_{\text {eff }}^{\mathrm{z}}
$$

where: $E_{\text {interg }}$ - an integrated criterion for evaluating outsourcing effectiveness;

$\mathrm{x}, \mathrm{y}, \mathrm{z}$ - coefficient weight of $\mathrm{E}_{\text {time }}, \mathrm{E}_{\mathrm{volume}}, \mathrm{E}_{\mathrm{eff}}$ respectively.

An increase in the integrated criterion indicates an improvement in the quality of service under the terms of the accounting outsourcing agreement. Accordingly, when deciding on further cooperation, one can use the generalized Harrington verbalnumeric scale, which characterizes the value of the criteria and is, in Pichkalev's (2012) view, versatile. Given the objectives of this study, the Harrington verbal-numeric scale was modified by authors in the context of accounting outsourcing (Table 3 ).

Table 3

Scale for process effectiveness levels when interacting with an outsourcer

\begin{tabular}{ccc}
\hline Numeric intervals & The level of efficiency & Actions to interact with the outsourcer \\
\hline $0,80-1,0$ & Very high level & Operates effectively, but need to develop measures to prevent deviations \\
\hline $0,63-0,80$ & High level & Need to develop minor corrective measures \\
\hline $0,37-0,63$ & Average level & The goals and objectives have been partially achieved and significant \\
& corrective measures are needed
\end{tabular}

This table presents a modified Harrington scale that determines the effectiveness of outsourcing processes. Depending on how effective outsourcing is in the context of planned and achieved results, several options are available.

With small deviations (0.8-1) there is only a slight disturbance of the outsourcing process, and therefore there is no need for significant steps to change the outsourcing model. In the case of a significant deviation (from 0 to 0.37 ), significant intervention is required in the form of various management decisions and other corrective actions necessary to restore the performance. Based on specific calculations and data analysis, you can evaluate the effectiveness of the outsourced option that is being used. However, to carry out such accurate assessments a large amount of information about the use of particular model outsourcing over a long period of time (several years) is required. Large amounts of information will test such methods regarding the presence of co-integration links and the detection of autocorrelation processes, which will allow to customize the models used more accurately.

In a structured form, the decision on accounting outsourcing and evaluation of its effectiveness is shown in Fig. 1.

To demonstrate the developed methodology for assessing the feasibility of accounting outsourcing transition, we will provide the procedure for such assessment, which was applied at LLC «Altmed».

LLC «Altmed» is tasked with minimizing costs through the use of accounting outsourcing. It means that the goal of transition to outsourcing will be to reduce the cost of LLC «Altmed»by optimizing transaction costs. In these circumstances, cost optimization will be ensured when the marginal profit-to-cost ratio of LLC «Altmed» under outsourcing conditions is greater than the marginal profit-to-cost ratio of LLC «Altmed» in the case of keeping records on its own. Thus, to make the decision on outsourcing of LLC «Altmed» it is necessary to compare these two values, and for this it is necessary to determine the amount of LLC «Altmed» expenses incurred by use of outsourcing.

According to LLC «Altmed», the marginal profit is UAH 75, and the cost on record keeping by LLC «Altmed» is UAH 35000. After the outsourcing implementation, the marginal profit of LLC «Altmed» will not change, as keeping records has no impact on it, but the cost of outsourcing is about 20,000 UAH per month:

$$
\frac{M P_{0}}{P_{0}}>\frac{M P_{i}}{P_{i}} ; \quad \frac{75}{20000}>\frac{75}{35000} ; 0,00375>0,00214
$$

Thus, the use of accounting outsourcing allows to minimize transaction costs of LLC «Altmed», i,e. transition to outsourcing is expedient.

The next step is to identify the accounting functions that LLC «Altmed» wants to outsource. In our case, to achieve the goal of transaction cost optimization, the management of LLC «Altmed» wants to transit all accounting functions to outsourcing, so the choice of functions is actually eliminated. 


\section{DECISION ON THE USE OF ACCOUNTING OUTSOURCING}

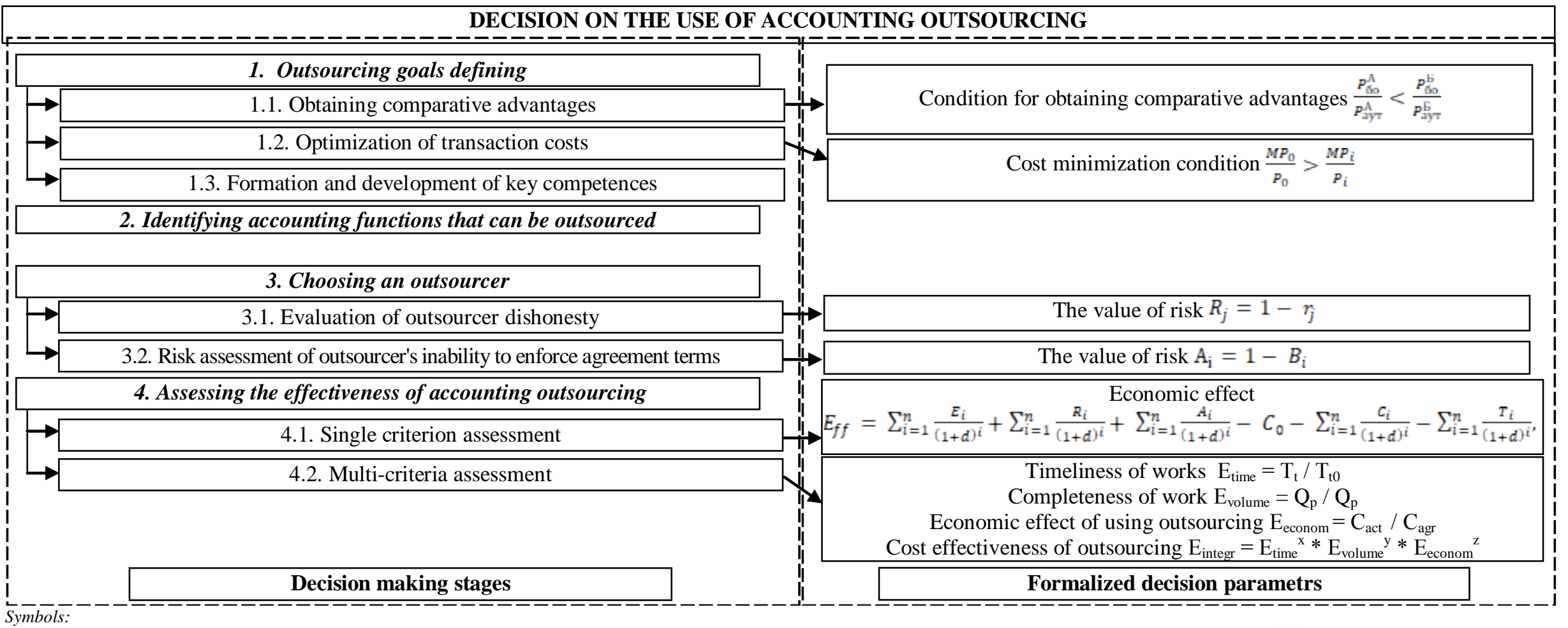

$P_{60}^{\mathrm{A}}-$ the costs of Company A for keeping records; $P_{\mathrm{ayT}}^{\mathrm{A}}-$ outsourcing costs of Company A; $P_{60}^{\mathrm{b}}-$ the costs of Company B for keeping records; $P_{\mathrm{ay} \mathrm{T}}^{\mathrm{b}}-$ outsourcing costs of Company B; $\frac{M P_{\mathrm{a}}}{P_{0}}-$ the ratio of marginal profit and cost under outsourcing; $\frac{M P_{t}}{P_{I}}$ - the ratio of marginal profit and cost under insourcing;

$R_{i}-$ additional income in the i-th year, obtained through the use of outsourcing; $A_{i}-$ other customer income in the i-th year that came from outsourcing; $\mathrm{B}_{\mathrm{i}}-$ the value of the risk of the outsourcer's inability to provide the required value of the $\mathrm{i}$-th characteristic; $r_{j}$ - the value of the risk of failure of the $\mathrm{j}$-th outsourcer to cooperate based on established arrangements;

$E_{f f}$ - the economic effect of outsourcing; $n$ - duration of outsourcing agreement (number of years); $d$ - discount rate; $E_{i}-$ the cost savings from outsourcing received in i-th year, presented by the difference between the cost of the enterprise to execute a particular process on its own and the costs associated with outsourcing the process; $C_{0}-$ the cost of searching the outsourcer; $C_{i}-$ costs of outsourcing management in i-th year (administrative, transportation expenses); $T_{i}$ - costs of transition to outsourcing in i-th year (business process reengineering, equipment purchase, compensation for redundant employees);

$\mathrm{E}_{\text {час }}-$ time outsourcing coefficient; $\mathrm{T}_{\mathrm{T}}-$ actual time of accounting outsourcing services; $\mathrm{T}_{\mathrm{T} 0}-$ scheduled under the terms of the agreement time to provide accounting outsourcing services; $\mathrm{E}_{\mathrm{volume}}-$ coefficient of the volume of accounting outsourcing services; $\mathrm{Q}_{\text {act }}$ - volume of accounting outsourcing services actually provided (for the relevant period of time); $\mathrm{Q}_{\mathrm{p}}$ - the volume of accounting outsourcing services planned under the terms of the agreement (for the relevant period of time); $\mathrm{E}_{\text {eff }}-$ coefficient of efficiency; $\mathrm{C}_{\text {act }}-$ actually incurred costs on outsourcing; $\mathrm{C}_{\text {agr }}-$ the amount of costs defined in the outsourcing agreement; $\mathrm{E}_{\mathrm{integr}}-$ an integrated criterion for evaluating outsourcing effectiveness; $\mathrm{x}, \mathrm{y}, \mathrm{z}$ - coefficient weight $\mathrm{E}_{\text {час }}, \mathrm{E}_{\text {обсяг }}, \mathrm{E}_{\text {економ }}$ respectively.

Fig. 1. The process of deciding on accounting outsourcing 
When choosing an outsourcing company, the management of LLC «Altmed» adheres to the simplest option, i.e. to consult with business partners. Based on recommendations and feedback, a company specializing in providing accounting consulting, tax law, accounting and outsourcing services was selected. The next step is to evaluate this company for dishonesty. In assessing the value of the risk of outsourcing, the cooperation of partner companies using the services of this firm was used to report the cases of non-cooperation. The management of LLC «Altmed» interviewed four partners and none of them mentioned the facts of the refusal, so the risk of refusal can be estimated at zero percent.

Thus, the unreliability of the selected company as outsourcer is evaluated at 0 . The obtained value is estimated according to the risk assessment scale of outsourcer's fraudulent behavior. A value of 0 implies that the outsourcer is absolutely reliable.

In assessing the risk of the outsourcer's inability to enforce the terms of the agreement, partners were also interviewed for cases where the selected company could not provide certain conditions for the provision of accounting outsourcing services, failure to complete the task or provide the necessary information timely. The survey did not reveal any such cases, so this risk is also assessed at zero level.

The risk of a company being unable to provide certain conditions for the provision of accounting outsourcing services is also assessed at level 0 , which also indicates the absolute reliability of the outsourcer according to the risk assessment scale. Since the selected company has the highest level of reliability, the management of LLC «Altmed» did not raise the issue of finding other outsourcing companies for comparison with the selected one.

To carry out a potential evaluation of outsourcing, the forecast calculations made by the accountants of LLC «Altmed»and financial managers were used before deciding on its use.

According to the single criterion approach, accounting outsourcing effectiveness is assessed by comparing the cost savings of outsourcing, the extra outsourcing income, and other company income that has resulted from outsourcing with costs of searching the outsourcer, outsourcing management costs, and outsourcing transition costs. According to the information provided by the management of the company, saving of money from the use of outsourcing $\left(E_{i}\right)$ is about UAH 25,000 per month, the company does not expect additional $\left(R_{i}\right)$ and other income $\left(A_{i}\right)$. Concerning the estimation of potential costs, the following data were provided: there are no costs of searching the outsourcer, outsourcing management costs $\left(C_{i}\right)$ are about UAH 20,000 per month, the one-off cost of transition to outsourcing $\left(T_{i}\right)$ is UAH 30,000 .

Based on the data obtained, we can calculate the economic effect of outsourcing for the first year of its use. We take the discount rate at the NBU discount rate at the beginning of 2020, i.e. $13.5 \%$ :

$$
E_{f f}=\frac{25000 * 12}{(1+0,135)}-\frac{20000 * 12}{(1+0,135)}-\frac{30000}{(1+0,135)}=26431,72 \text { грн. }
$$

It is currently not possible to carry out a multi-criteria assessment of outsourcing effectiveness, since actual outsourcing performance metrics that are not available at the planning stage are required to calculate time outsourcing coefficient, coefficient of the volume of accounting outsourcing services, coefficient of outsourcing efficiency.

The suggested technique of analysis of the accounting outsourcing expediency and effectiveness has been tested at several other entities. At the same time in different entities the initial conditions, such as industry, entity management style, understanding of accounting functions in entity management by management staff differ, but all owners are unanimous in that the transition to outsourcing should at least lead to reduction of expenses for keeping records, otherwise it is not expedient. Let's analyze the evaluation results of the expediency of transition to outsourcing at these entities, in particular PP «Prombudservis», PP «Spets-Kom», PP «Vest-MIM» and LLC «Logistics Service Kalush».

$P P \ll P R O M B U D S E R V I S »$

According to PP «PROMBUDSERVIS» data, the marginal profit is UAH 43, and the costs of the PP «PROMBUDSERVIS» for keeping records are UAH 28,400. After the implementation of outsourcing and liquidation of the accounting service marginal profit of PP «PROMBUDSERVIS» will not change. The costs of outsourcing are estimated by the management of the company to be about UAH 18,000 per month:

$$
\frac{M P_{0}}{P_{0}}>\frac{M P_{i}}{P_{i}} ; \quad \frac{43}{18000}>\frac{43}{28400} ; 0,00238>0,00151
$$

The use of accounting outsourcing allows to minimize transaction costs of PP «PROMBUDSERVIS», i.e. the transition to outsourcing is expedient from the point of view of reducing the expenses of the entity.

The next step is to identify the accounting functions that PP «PROMBUDSERVIS» wants to outsource. As the main task of reforming the organizational structure of the entity is to reduce costs, it is planned to outsource all accounting functions.

The choice of outsourcer was made on the basis of business relations - on the advice of business partners. Based on recommendations and feedback, a company specializing in providing accounting consulting, tax law, accounting and outsourcing services was selected. Evaluating the outsourcer dishonesty the feedback of partners were taken into account. The management of PP «PROMBUDSERVIS» had interviewed two partners who use the services of this outsourcer, but one of them stated that the company was satisfied with the work and the other that there were some difficulties in the process of arranging the terms of cooperation. In particular, the manager of PP «PROMBUDSERVIS» wanted to have 24/7 access to his accounting data, but this caused technical problems. However, this situation does not reduce the reliability of the outsourcer, and therefore the risk indicator is minimal. 
In assessing the risk of the outsourcer's inability to enforce the terms of the agreement, partners were also interviewed for cases where the selected company could not provide certain conditions for the provision of accounting outsourcing services, failure to complete the task or provide the necessary information. No such cases were identified by the survey, so this risk is also assessed at zero.

The risk of a company being unable to provide certain conditions for the provision of accounting outsourcing services is also assessed at level 0 , which also indicates the absolute reliability of the outsourcer according to the risk assessment scale. Since the selected company has the highest level of reliability, the management of PP «PROMBUDSERVIS» did not raise a question about finding other outsourcing companies for comparison with the selected one.

To make a potential assessment of outsourcing, the forecast calculations provided by the accountants and financial managers of PP «PROMBUDSERVIS» were used before making a decision on its use.

According to the information provided by the management of the entity, the savings of funds from the use of outsourcing $\left(E_{i}\right)$ should be about UAH 24,000 per month, the company does not expect additional $\left(R_{i}\right)$ and other income $\left(A_{i}\right)$. Concerning the estimation of potential costs, the following data were provided: there are no costs of searching the outsourcer, outsourcing management costs $\left(C_{i}\right)$ are about UAH 18,000 per month, the one-off cost of transition to outsourcing $\left(T_{i}\right)$ is UAH $28,000$.

Based on the data obtained, we can calculate the economic effect of outsourcing for the first year of its use:

$$
E_{f f}=\frac{24000 * 12}{(1+0,135)}-\frac{18000 * 12}{(1+0,135)}-\frac{28000}{(1+0,135)}=38766,52 \text { грн }
$$

\section{$P P \ll$ Spets-Kom»}

According to PP «Spets-Kom» data marginal profit is UAH 12, and the costs of PP «Spets-Kom» for keeping records are UAH 26,600. After the implementation of outsourcing marginal profit of PP «Spets-Kom» will not change, as accounting has no influence on it, but the cost of outsourcing is about UAH 23,000 per month:

$$
\frac{M P_{0}}{P_{0}}>\frac{M P_{i}}{P_{i}} ; \quad \frac{12}{23000}>\frac{12}{26600} ; 0,00052>0,00045
$$

Thus, the use of accounting outsourcing allows to minimize transaction costs of PP «Spets-Kom», i.e. the transition to outsourcing is expedient. The owner of PP «Spets-Kom» wants to transit all accounting functions to outsourcing.

The choice of outsourcer, management of PP «Spets-Kom» made using information from the Internet. After analyzing the suggestions, the management selected only one company and asked its partners about it. Due to the fact that no negative feedback was received, the owner made his choice on this outsourcing company for further evaluation. Thus, the risk of failure was estimated at 0 . The obtained value is evaluated according to the risk assessment scale of fraudulent behavior of the outsourcer. A value of 0 implies that the outsourcer is absolutely reliable.

In assessing the risk of the outsourcer's inability to enforce the terms of the agreement, partners were also interviewed for cases where the selected company could not provide certain conditions for the provision of accounting outsourcing services, failure to complete the task or provide the necessary information. The survey did not reveal any such cases, so this risk is also assessed at zero.

According to the information provided by the management of the company, the savings of funds from the use of outsourcing $\left(E_{i}\right)$ should be about UAH 23,000 per month, the company does not expect additional $\left(R_{i}\right)$ and other income $\left(A_{i}\right)$. Concerning the estimation of potential costs, the following data were provided: there are no costs of searching the outsourcer, outsourcing management costs $\left(C_{i}\right)$ are about UAH 18,000 per month, the one-off cost of transition to outsourcing $\left(T_{i}\right)$ is UAH 28,000.

На основі отриманих даних можемо порахувати економічний ефект від аутсорсингу за перший рік його використання. Ставку дисконтування візьмемо на рівні облікової ставки НБУ на початок 2020 року, тобто 13,5 \%:

Based on the data obtained, we can calculate the economic effect of outsourcing for the first year of its use. We take the discount rate at the NBU discount rate at the beginning of 2020, i.e. 13,5\%:

$$
E_{f f}=\frac{23000 * 12}{(1+0,135)}-\frac{18000 * 12}{(1+0,135)}-\frac{28000}{(1+0,135)}=28193,83 U A H .
$$

$P P \ll V e s t-M I M »$

According to PP «Vest-MIM» data marginal profit is UAH 88, and the cost of PP «Vest-MIM» for for keeping records is UAH 15,000. After the implementation of outsourcing, marginal profit of PP «Vest-MIM» will not change, as accounting has no impact on it, but the cost of outsourcing is about UAH 18,000 per month:

$$
\frac{M P_{0}}{P_{0}}>\frac{M P_{i}}{P_{i}} ; \quad \frac{88}{12000}>\frac{88}{15000} ; 0,00733>0,00586
$$

Thus, the use of accounting outsourcing allows to minimize transaction costs of PP «Vest-MIM», i.e. the transition to outsourcing is expedient. 
To achieve the goal of transaction cost optimization, the management of PP «Vest-MIM» wants to transit all accounting functions to outsourcing.

The choice of outsourcer was made based on experience of the head of the company in cooperation with this company in the past, so there was confidence in the reliability of this company. The risk of failure was estimated at zero.

A value of 0 implies that the outsourcer is absolutely reliable. Assessing the risk of the outsourcer's inability to enforce the terms of the agreement was also conducted on the basis of personal experience of dealing with this company. Therefore, this risk is also assessed at zero level.

The risk of a company being unable to provide certain conditions for the provision of accounting outsourcing services is also assessed at level 0 , which also indicates the absolute reliability of the outsourcer according to the risk assessment scale. Since the selected company has the highest level of reliability, the management of PP «Vest-MIM» has not raised the issue of finding other outsourcing companies for comparison with the selected one.

According to the information provided by the management of the entity, saving of funds from the use of outsourcing $\left(E_{i}\right)$ should be about UAH 12,000 per month, the entity does not expect additional $\mathrm{v}$ and other income $\left(A_{i}\right)$. Concerning the estimation of potential costs, the following data were provided: there are no costs of searching the outsourcer, outsourcing management costs $\left(C_{i}\right)$ are about UAH 12,000 per month, the one-off cost of transition to outsourcing $\left(T_{i}\right)$ is UAH $22,000$.

Based on the data obtained, we can calculate the economic effect of outsourcing for the first year of its use:

$$
E_{f f}=\frac{12000 * 12}{(1+0,135)}-\frac{12000 * 12}{(1+0,135)}-\frac{22000}{(1+0,135)}=-19383,26 \text { грн. }
$$

\section{LLC «Logistics Service Kalush»}

According to LLC «Logistics Service Kalush» data marginal profit is UAH 36, and the costs of LLC «Logistics Service Kalush»for keeping records are UAH 28,400. After the implementation of outsourcing, the marginal profit of LLC «Logistics Service Kalush» will change to UAH 38, as it is expected that part of the employees dismissed from the accounting department will be employed in other divisions of the enterprise, which will increase productivity and increase marginal profit. Outsourcing costs are about UAH 18,000 per month:

$$
\frac{M P_{0}}{P_{0}}>\frac{M P_{i}}{P_{i}} ; \quad \frac{38}{29000}>\frac{36}{43200} ; 0,00131>0,00083 .
$$

Thus, the use of accounting outsourcing allows to minimize transaction costs of LLC «Logistics Service Kalush», that is, transition to outsourcing is expedient.

The management of LLC «Logistics Service Kalush» wants to transit all accounting functions to outsourcing, in order to use the dismissed employees more effectively in other divisions of the company.

Based on recommendations and feedback, a company specializing in the provision of accounting consulting, tax law, keeping records and accounting outsourcing was selected. The management of LLC «Logistics Service Kalush» interviewed the partners and none of them mentioned the fact of failure to fulfill their responsibilities as outsourcer, so the risk of failure can be estimated at zero percent.

Thus, the unreliability of the selected company as an outsourcer is rated at 0 . For assessing the risk of the outsourcer's inability to enforce the terms of the agreement, partners were also interviewed for cases where the selected company could not provide certain conditions for the provision of accounting outsourcing services, failure to complete the task or delivery necessary information. No such cases were identified by the survey, so this risk is also assessed at zero.

The risk of a company being unable to provide certain conditions for the provision of accounting outsourcing services is also assessed at level 0 , which also indicates the absolute reliability of the outsourcer according to the risk assessment scale. As the selected company has the highest level of reliability, the management of LLC «Logistics Service Kalush» did not have a question about finding other outsourcing companies for comparison with the selected one.

According to information provided by the management of the company, the savings of funds from the use of outsourcing $\left(E_{i}\right)$ should be about UAH 33,000 per month, the company does not expect additional $\left(R_{i}\right)$ and other income $\left(A_{i}\right)$. Concerning the estimation of potential costs, the following data were provided: there are no costs of searching the outsourcer, outsourcing management costs $\left(C_{i}\right)$ are about UAH 29,000 per month, the one-off cost of transition to outsourcing $\left(T_{i}\right)$ is UAH 49,000 .

Based on the data obtained, we can calculate the economic effect of outsourcing for the first year of its use:

$$
E_{f f}=\frac{33000 * 12}{(1+0,135)}-\frac{29000 * 12}{(1+0,135)}-\frac{49000}{(1+0,135)}=-881,06 U A H
$$

After testing the suggested technique, we can summarize the obtained results (Table 4). 
Table 4

Results of expediency defining of accounting outsourcing transition

\begin{tabular}{|c|c|c|c|c|c|c|}
\hline \multirow[b]{2}{*}{ No. } & \multirow[b]{2}{*}{ Indicator } & \multicolumn{5}{|c|}{ Entity } \\
\hline & & $\begin{array}{c}\text { LLC } \\
\text { «Altmed» }\end{array}$ & $\begin{array}{c}\text { PP } \\
\ll \text { Prombudservis» }\end{array}$ & $\begin{array}{c}\mathrm{PP} \\
\text { «Spets-Kom» }\end{array}$ & $\begin{array}{c}\mathrm{PP} \\
« \text { Vest-MIM» }\end{array}$ & $\begin{array}{l}\text { LLC } \\
\text { «Logistics } \\
\text { Service } \\
\text { Kalush» } \\
\end{array}$ \\
\hline 1 & $\begin{array}{c}\text { The purpose of } \\
\text { accounting } \\
\text { outsourcing }\end{array}$ & $\begin{array}{l}\text { transaction costs } \\
\text { minimizing }\end{array}$ & $\begin{array}{l}\text { transaction costs } \\
\text { minimizing }\end{array}$ & $\begin{array}{l}\text { transaction costs } \\
\text { minimizing }\end{array}$ & $\begin{array}{l}\text { transaction costs } \\
\text { minimizing }\end{array}$ & $\begin{array}{l}\text { transaction } \\
\text { costs } \\
\text { minimizing }\end{array}$ \\
\hline \multirow[t]{2}{*}{2} & $\begin{array}{c}\text { Is the cost } \\
\text { minimization } \\
\text { condition fulfilled }\end{array}$ & yes & yes & yes & yes & yes \\
\hline & $\left(\frac{M P_{0}}{P_{0}}>\frac{M P_{i}}{P_{i}}\right)$ & $0,00375>0,00214$ & $0,00238>0,00151$ & $0,00052>0,00045$ & $0,00733>0,00586$ & $\begin{array}{c}0,00131>0,00 \\
083\end{array}$ \\
\hline 3 & $\begin{array}{c}\text { Accounting } \\
\text { functions transited } \\
\text { to outsourcing }\end{array}$ & all & all & all & all & all \\
\hline 4 & $\begin{array}{c}\text { Evaluation of } \\
\text { outsourcer } \\
\text { dishonesty (risk } \\
\text { value at } \min =0 \\
\max =1 \text { ) }\end{array}$ & $R_{j}=0$ & $R_{j}=0$ & $R_{j}=0$ & $R_{j}=0$ & $R_{j}=0$ \\
\hline 5 & $\begin{array}{l}\text { Risk assessment of } \\
\text { outsourcer's } \\
\text { inability to enforce } \\
\text { agreement terms } \\
\text { (risk value at } \\
\text { min=0 max }=1 \text { ) }\end{array}$ & $A_{j}=0$ & $A_{j}=0$ & $A_{j}=0$ & $A_{j}=0$ & $A_{j}=0$ \\
\hline 6 & $\begin{array}{c}\text { Economic effect, } \\
\text { UAH. }\end{array}$ & $+26431,72$ & $+38766,52$ & $+28193,83$ & $-19383,26$ & $-881,06$ \\
\hline
\end{tabular}

The conducted analysis shows that for PP «Vest-MIM» as well as for LLC «Logistics Service Kalush» from an economic point of view, outsourcing accounting transition is inexpedient as the economic effect index is negative. At the same time, for other entities, accounting outsourcing has a positive economic effect and will really enable to reduce the costs of the entity as well as to increase the effectiveness of using the funds and other resources of the entity.

\section{Concluding remarks}

In order to provide a methodical toolkit for the assessment of the cost effectiveness of the accounting outsourcing transition, it is suggested to use a multi-criteria approach. The suggested multi-criteria approach to assessing the effectiveness of accounting outsourcing transition includes the following indicators:

- the suggested list of entity's expenses on keeping records as well as on using outsourcing;

- timely performance of works and provision of services in accordance with the terms of the outsourcing agreement;

- completeness of works and services in accordance with the terms of the outsourcing agreement;

- cost effectiveness of outsourcing.

The use of the suggested indicators allows to evaluate the results of the use of accounting outsourcing from various aspects as well as to justify the decision on its further extension.

The testing of the suggested technique for assessing the expediency of accounting outsourcing transition has shown that the use of this technique greatly simplifies and structures the process of making such a decision. According to the results of the calculations, it was proved the expediency of accounting outsourcing transition for three entities: LLC «Altmed», PP «Prombudservis», PP «Spets-Kom». The use of accounting outsourcing is not appropriate for PP «Vest-MIM». For all of above mentioned entities, the primary purpose of considering the use of accounting was to reduce the costs of the entity by reducing transaction costs. Although for LLC «Logistics Service Kalush» the economic effect from the use of accounting outsourcing is negative (UAH -881,06), but allows the released labor resources to be used in other areas of the entity. This, in turn, will increase marginal profit from UAH 36 up to UAH 38. In view of this, LLC «Logistics Service Kalush» is recommended to transit business processes of accounting into outsourcing, as this will increase the marginal profit of the entity, which is positive in view of the possibility of increasing production volumes due to the reserve covering of additional marginal costs in the amount of UAH 2 per unit. 


\section{References:}

1. Alyoshina, E.I. (2014), «Metodika ocenki effekta ot primeneniya autsorsinga kak metoda reinzhiniringa organizacionnoj struktury predpriyatiya», Molodezh i nauka, sbornik materialov X Yubilejnoj Vserossijskoj nauchno-tehnicheskoj konferencii studentov, aspirantov i molodyh uchenyh s mezhdunarodnym uchastiem, posvyashennoj 80-letiyu obrazovaniya Krasnoyarskogo kraya, Sibirskij federalnyj un-t, Krasnoyarsk, [Online], available at: http://conf.sfu-kras.ru/sites/mn2014/directions.html

2. Anikin, B.A. and Rudaya, I.L. (2017), Autsorsing i autstaffing: vysokie tehnologii menedzhmenta, Infra-M, Moscow, 330 p.

3. Bulgakova, I.N. and Morozov, A.N. (2009), «Ispolzovanie «Funkcii Zhelatelnosti» dlya formalizacii kompleksnogo pokazatelya konkurentosposobnosti promyshlennogo predpriyatiya», Vestnik VGU, Seriya Ekonomika i upravlenie, Issue 2, pp. 54-56, [Online], available at: http://www.vestnik.vsu.ru/pdf/econ/2009/02/2009-02-08.pdf

4. Davydkin, E.V. (2011), «Nechetkaya model ocenki effektivnosti autsorsinga», Vestnik TGPU, Issue 12, pp. 162-165.

5. Dubrovskaya, T.N. (2016), «Effektivnost raboty predpriyatij na usloviyah autsorsinga», Vestnik MGSU, Issue 4, pp.108-118, [Online], available at: https://doi.org/10.22227/1997-0935.2016.4.108-118

6. Eggertsson, T. (2001), Ekonomicheskoe povedenie i instituty, Delo, Moscow, pp. 36-38.

7. Giertl, G., Potkány, M. and Gejdoš, M. (2015), «Evaluation of Outsourcing Efficiency through Costs for its Use», Procedia Economics and Finance, Issue 26, pp. 1080-1085, [Online], available at: doi: 10.1016/S2212-5671(15)00933-8

8. Isavnin, A.G. and Farkhoutdinov, I.I. (2013), Features of application of industrial outsourcing at the Russian automobile building enterprise, LAP LAMBERT Academic Publishing, AV Akademikerverlag GmbH \& Co, KG, Saarbrücken, [Online], available at: doi:10.14419/ijet.v7i3.27.18501

9. Kang, M., Wu, X. and Hong, P. (2009), «Strategic outsourcing practices of multi-national corporations (MNCs) in China», Strategic Outsourcing: An International Journal, Vol. 2 (3), pp. 240-256, [Online], available at: doi: 10.1108/17538290911005153

10. Kotlyarov, I. (2010), «Prinyatie resheniya ob ispolzovanii autsorsinga na osnove ocenki ego effekta dlya predpriyatiya», Innovacii, Issue 9, pp. 88-92.

11. Kotlyarov, I. (2013), «Prinyatie autsorserom resheniya o sotrudnichestve s zakazchikom na osnove kriteriya ozhidaemogo ekonomicheskogo effekta». Problemy ekonomiki i upravleniya neftegazovym kompleksom, Issue 7, pp. 15-20.

12. McIvor, R., Humphreys, P., Wall, A. and McKittrick, A. (2009), A Study of Performance Measurement in the Outsourcing Decision, CIMA publishing, UK, [Online], available at: http://www.cimaglobal.com/documents/importeddocumen ts/cid_ressum_a_study_of_performance_measurement_in_the_outsourcing_decision_dec08.pdf

13. Pichkalev, A.V. (2012), «Obobshennaya funkciya zhelatelnosti Harringtona dlya sravnitelnogo analiza tehnicheskih sredstv», Kosmicheskie apparaty i tehnologii, Issue 1, pp. 25-28.

14. Porter, M. (2006), Konkurenciya, Vilyams, Moscow, 608 p.

15. Shmigol, N. (2010), «Autsorsing yak metod optimizaciyi sub'yekta gospodaryuvannya», Derzhava ta regioni, Seriya Ekonomika $i$ pidpriyemnictvo, Issue 4, pp.194-197.

16. Skakun, L.S. (2010), Buhgalterskij oblik v umovah autsorsingu, Abstract of the diss. ... k.e.n., spec. 08.00.09, Zhytomyr. derzh. tehnol. un-t, Zhitomir, $21 \mathrm{p}$.

17. Vitasek, K. (2013), Vested Outsourcing: Five Rules That Will Transform Outsourcing, 2nd ed, Palgrave Macmillan, New York, 227 p.

${ }^{* *}$ How to cite this article: Lyakhovich G., Horodysky M., Hrabchuk I., Vakun O. Effectiveness analysis accounting outsourcing transition. Public Policy and Accounting. 2020, Vol. 1. https://doi.org/10.26642/ppa-2020-1-30-43 